\title{
СТАТУС ТУРКМЕНИСТАНА КАК ПОСТОЯННО НЕЙТРАЛЬНОГО ГОСУДАРСТВА
}

\author{
E.A. K е п 6 ан о в*
}

Современный Туркменистан, уверенно идуший по пути цивилизационного развития и проводящий активный внешнеполитический курс на международной арене, все больше привлекает внимание мирового сообщества. Место и роль Туркменистана как в региональном, так и в глобальном смысле обозначены, согласно его концептуальной внешнеполитической модели, в качестве постоянного нейтрального государства, признанного международньм сообществом наций.

Свидетельством такого признания стало историческое заседание Генеральной Ассамблеи ООН, состоявшееся 12 декабря 1995 r., на котором при единогласном голосовании представителей всех 185 государств - членов ООН была принята специальная резолюция “Постоянный нейтралитет Туркменистана"1.

Объективный анализ политического курса Туркменистана, в том числе его внешнеполитической стратегии, приводит к выводу о том, что концепция позитивного нейтралитета является оптимальной моделью национально-государственного развития страны. Она сочетает в себе перспективы развития страны с тенденциями региональных и глобальных процессов, национальные интересы с объективными требованиями дня. Концептуальная модель нейтрального статуса Туркменистана базируется на глубоком осмыслении философско-правовых аспектов современного мирового и регионального развития с учетом самобытности, традиций и исторической роли туркменского народа, его менталитета.

Жизнь доказала правомерность политической линии, выработанной правительством страны в начальный период распада глобальной системы, построенной на биполярном балансе, хогда на первый план были поставлены задачи обеспечения региональной стабильности и безопасности в Центральной Азии. Эти задачи были непосредственно связаны с проблемами глобального структурирования международных отношений в новых условиях.

Нейтралитет Туркменистана стал достойным ответом на исторический вызов времени, когда туркменский народ оказался перед необходимостью осознанного выбора своего места в геополитической и геоэкономической системе современности. Для правительства

\footnotetext{
* Кандидат юридических наук, заместитель министра иностранных дел Туркменистана.
} 
этот. выбор был связан с принятием на себя значительной доли ответственности при разработке и осуществлении как внутри-, так и внешнеполитического курса страны.

Идея нейтралитета Туркменистана базируется на системноп анализе взанмообусловленных факторов, имеющих геоэкономи. ческое и геополитическое значенне. В условиях Туркменистана с его 5-миллионньм населением и в то же время относительно большой территорией, наделенной огромными природными богатствами, естественным образом на переднем плане оказались факторы экономического характера.

Геостратегическое расположение Туркменистана, его огромные запасы углеводородного сырья обусловливают постоянный интерес $\mathrm{x}$ нему со стороны крупных держав мира. Сегодня лишь на одной трети территории Туркменистана проведены научно-изыскательские работы. Но и здесь запасы газа превышают 20 трлн. куб. м. На шельфе Каспия и берегах Амударьи сокрыты богатейшие залежи нефти, запасы которых на сегодня превышают 12 млрд. т. Туркменистан может гарантировать поставку на мировой рынок ежегодно свыше 100 млрд. куб. м газа.

Кроме того, одним из главных факторов, служащих обоснованием идеи нейтралитета, являлась историческая специфика туркменского народа, который всегда отличался своим миролюбием и добрососедством, высоким трудолюбием и самобытностью. Верность традиционным укладам и религии, уважение и преклонение перед авторитетом старейшины (будь то глава семьи или всего государства) также являются неотъемлемыми свойствами туркменского общества. В немалой степени подобную прочность обшественного фундамента можно объяснить природно-географической спецификой Туркменистана: ведь выживание в пустынных зонах аридного (засушливого) климата, где каждая капля воды сравнима по стоимости с золотом, было бы просто невозможно без прочных семейных укладов, без мирного согласия с соседями.

Идея нейтралнтета также связана с тем, что обретение независимости Туркменистаном стало воплощением вековой мечты туркменского народа о своем очаге, о своем государстве. Необходимо было использовать этот уникальный шанс в судьбе туркменского народа с тем, чтобы обеспечить и на века сохранить независимость, свою государственность. Историческим фундаментом использования такой возможности было то, что за долгие столетия своей истории туркмены накопили мощный духовный потенциал, сохранив при этом свою национальную самобытность, богатое наследие, берущее начало в таких древнейших цивилизациях, как Парфянская, Сельджукская и др.

Придерживаясь политики позитивного нейтралитета и в результате всестороннего анализа обозначенных выше обстоятельств ру- 
ководство Туркменистана во главе с первым Президентом Сапармуратом Туркменбаши с самого начала независимости взяли установку на то, чтобы не копировать никакие модели, а исходить из имеющихся реалий. Критерием выбора пути было то, что высшим проявлением свободы волеизъявления народа является его право на выбор. Высшим правом каждого независимого народа и государства являеся выбор пути собственного развития, выбор приемлемой формулы государственного устройства.

Следуя такой логике, с первых дней обретения независимости Туркменистан спокойно, без политического романтизма начал реализовывать программу национально-государственного строительства, построения системы внешних связей, поиск оптимальных путей участия в международных отношениях на основе собственных национальных интересов. Каждый шаг сверялся, с одной стороны, с национальными интересами Туркменистана, а с другой - с требованиями стабилизация в регионе, укреплением международной безопасности. Эти задачи нельзя было отделить одну от другой.

На этой основе была разработана собственная, с учетом национальной особенности, модель, которая стала стержнем одобренной Народным советом программы "Десять лет стабильности". Поэтапное выполнение этой программы позволило избежать потрясений и социальных конфликтов, удержать страну в поле эволюционньіх преобразований, снискать Туркменистану авторитет миротворческого государства, заинтересованного не только во внутренней стабильности, но в установлении мира и цивилизованных отношений в регионе и во всем мире.

В программе "Десять лет стабильности" были тесно увязаны стратегические задачи внутренней и внешней политики государства. Задачи обеспечения внутриполитической стабильности были нацелены на создание условий для осуществления глубоких реформ в государственной и общественной жизни, экономике страны. Внешнеполитическая линия государства была направлена на обеспечение стабильности вокруг государства, что позволяло налаживать эффективное торгово-экономическое сотрудничество с соседними странами, осуществлять планомерную интеграцию в мировое хозяйство.

Согласно избранному курсу реформ, в Туркменистане за короткое время были сформированы новые институты государственной власти и управления, которые соответствуют традициям и обычаям, а также менталитету народа. На новый качественный уровень была поднята политическая система государства, не допуская при этом социальных потрясений и расслоений общества по политическим группировкам.

Укрепление основ государственности велось одновременно с твердым соблюдением главного критерия реформ в обшестве - 
обеспечением социальной защищенности населения и планомерного перехода $\mathrm{K}$ рыночной экономике. Этому способствовала осуществляемая и по сей день политика государственного регулирования ключевых отраслей экономики и обеспечения населения гарантированным минимумом социально-бытовых условий жизни.

Такой ориентир государственной политики не является случайным. Исторический опыт свидетельствует, что в мировой практике существенных успехов в экономике добились именно те страны, которые сумели эффективно использовать возможности государственного регулирования экономических процессов, включая переход к рынку и развитие широкого предпринимательства. Ведь если вспомнить историю США, самое начало их зарождения, то можно увидеть, что первые 15-20 лет отцы-основатели демократического строя твердо проводили в жизнь политику государственного регулирования.

Все это способствовало обеспечению в стране гражданского мира и стабильности, плавного перехода обшества в новое качество. Благодаря этим мерам население Туркменистана фактически не почувствовало последствий тех испытаний и тяжестей, которые пришлись на долю многих других стран в результате недостаточно обдуманного применения так называемой "шоковой терапии". Претворению в жизнь этих мер во многом способствовала созданная в стране система сильной президентской власти, обеспечивающей политические, экономические, социальные и другие преобразования в обществе и государстве.

Курс на достижение статуса нейтрального государства подкреплялся конкретными практическими мерами на внешнеполитической арене. В течение более четырех лет, предшествовавших признанию нейтралитета, руководство Туркменистана последовательно, шаг за шагом шло к достижению поставленной цели. За сравнительно короткий исторический период была проделана колоссальная работа, получившая признание со стороны лидеров всех соседних государств, а также великих держав.

В июле 1992 года на встрече глав государств и правительств участников Совещания по безопасности и сотрудничеству в Европе (ныне ОБСЕ) Президент Туркменистана С.А. Ниязов впервые провозгласил позитивный нейтралитет в политике и открытость в экономике в качестве своих ключевых принципов ${ }^{2}$.

15 марта 1995 г. на третьей встрече глав государств - членов Организации экономического сотрудничества в г. Исламаб̆аде Президент Туркменистана С.А. Ниязов выступил с заявлением, в котором подчеркнул, что Туркменистан конституционно берет на себя все обязательства по статусу постоянно нейтрального государства и о готовности выступить в качестве миротворческого центра в регионе при соответствующих международных гарантиях. 
Выступая в Исламабаде, Президент Туркменистана высказал выходящие, на первый взгляд, за рамки повестки дня и неординарные для Центральноазиатского региона предложения. Как отметил Сапармурат Туркменбаши, Азиатский континент никогда не имел центра, где можно было бы без каких-либо условностей решать острые международные проблемы. Полностью признавая вклад политических и миротворческих центров Австрии и Швейцарии в историю международных отношений, он подчеркнул, что новые политические реалии диктуют необходимость создания подобных центров и в Азии ${ }^{3}$.

А в принятой на саммите Исламабадской декларации страны участницы Организации экономического сотрудничества (Афганистан, Иран, Пакистан, Турция, Азербайджан, Казахстан, Кыргызстан и Таджикистан) приветствовали заявление Президента Туркменистана и выразили готовность всемерно поддержать Туркменистан в его намеренни. Вслед за странами ОЭС намерение Туркменистана поддерхали Российская Федерация, Франция, Великобритания, ФРГ, КНР, Индия, Индонезия, Малайзия, Австрия, Румыния, Египет, Израиль, Украина, Армения, Чехия, Словакия, Венгрия и др.

Тот факт, что идея нейтралитета была выдвинута в Нсламабаде, имеет логическую обусловленность: Туркменистан прежде всего должен был заручиться поддержкой своих непосредственных соседей, чтобы затем апеллировать к мировому сообществу.

И наконец, 20 октября 1995 г. на встрече глав государств и правительств стран - участниц Движения неприсоединения в г. Картахене (Колумбия) Туркменистан не только стал полноправным 1 14-м членом этого Движения, но и получил полную поддержку своего нейтрального курса всеми его членами.

Результатом кропотливой работы стало то, что в итоге Туркменистан доказал, что может соответствовать статусу нейтрального государства, что было подтверждено на историческом заседании Генеральной Ассамблеи ООН 12 декабря 1995 г., когда все члены сообщества наций единогласно приняли специальную резолюцию “О постоянном нейтралитете Туркменистана".

Причем очевидно, что позволить себе серьезно заявить о своем нейтральном статусе может страна, обладающая рядом необходимых для этого характеристик.

Во-первых, в стране благодаря усилиям правительства Туркменистана сохраняется мир и внутренняя стабильность, созданы надежные социальные гарантии, что является одним из ключевых моментов для проведения нейтрального курса.

Во-вторых, что немаловажно, была создана и постоянно развивается мощная инфраструктура для проведения самых различных международных форумов. В стране построены международный аэро- 
порт, сеть комфортабельных отелей, бизнес-центры, создаются развитые транспортные коммуникации, современная, отвечающая мировым стандартам телефонная связь и т.д.

В-третьих, Туркменистан, в 1992 году став полноправным членом ООН, ОБСЕ и других международных организаций, в своей внешней политике руководствуется общепризнанными принципами и нормами международного права: мирного сосуществования, отказа от применения силы, невмешательства во внутренние дела других государств и т.д.

В-четвертых, Туркменистан одним из первых безоговорочно присоединился $\mathbf{x}$ ряду международных договоров и конвенций $о$ нераспространении ядерного и других видов оружия массового поражения. В частности, Туркменистан ратифицировал Договор о нераспространении ядерного оружия, Конвенцию о запрещении разработки, производства и накопления запасов бактериологического (биологического) и токсичного оружия и об их уничтожении и др.

B-пятых, Турхменистан не имеет на своей территории военных баз и воинских формирований иностранных государств. Наше государство не присоединилось ни $\mathrm{K}$ какому-либо военному или военнополитическому союзу или альянсу, другим организациям с жестко регламентированными функциями. В частности, будучи членом СНГ, Туркменистан не входит в Совет коллективной безопасности Содружества. Туркменистан не имеет никаких территориальных и иных споров с каким-либо из государств.

В чем же особенность туркменского феномена нейтралитета? Для того чтобы выяснить юридическую природу постоянного нейтралитета Туркменистана, важно охарактеризовать институт нейтралитета в целом.

Постоянный нейтралитет - это правовой статус государства, в соответствии с которым оно обязано воздерживаться от войны, не вступать в нее на стороне какого-либо воюющего государства (кроме случаев самообороны) и не оказывать воюющим военную помощь, а в мирное время проводить миролюбивую внешнюю политику, укреплять дружбу с другими государствами, не участвовать в военных союзах и коалициях, не заключать соглашений, которые могут вовлечь постоянно нейтральное государство в войну4.

Политика нейтралитета, конечно, не может быть какой-то самоцелью: это способ сохранения безопасности нации и государства при возникновении войны путем удержания страны вне военных действий ${ }^{5}$.

Представляя собой сложный международно-правовой институт, нейтралитет прошел в своем развитии длительный и сложный путь, окончательно сложившийся $\mathrm{K}$ началу XIX века. Практика нейтралитета отдельного государства сама по себе не нова. Например, нейт- 
ралитет Швейцарии берет свое начало в 1815 году, с момента принятия Декларации о делах Гельветического Союза. Нейтралитет Бельгии был определен в 1831 году и просуществовал до 1919 года. Подобная судьба нейтралитета сложилась и в отношении Люксембурга. В последуюший исторический период вынашивалось еше несколько проектов установления нейтралитета государств, например, в отношении Греции, Афганистана, Египта, группы Скандинавских стран. Но всем им суждено было остаться только в виде идей, в лучшем случае - в качестве неудавшихся проектов. Фактически только Швейцарии удалось сохранить свой нейтральный статус. Кроме того, с 1955 года статусом постоянного нейтралитета обладает также и Австрия.

Как правило, исторические прецеденты нейтралитета государств, включая Швейцарию, покоились на известном так называемом "праве на войну", т.е. институт нейтралитета было принято связывать с войной. Инициатива нейтралитета какого-либо государства исходила прежде всего не от самого государства, а от группы стран, находящихся между собой в состоянии войны. При нарушении баланса сил сводилась на нет и сама идея нейтралитета.

В этом контексте разработаны и Гаагские конвенции 1907 года, посвященные нейтралитету, которые устанавливают права и обязанности нейтральных государств в период войны по отношению к воююшим странам. Однако что касается обязательств нейтральных государств в мирное время, то они не охвачены международно-правовым регулированием. В данном случае речь идет о постоянно нейтральных государствах, которые должны придерживаться своего статуса не только в военное, но и в мирное время. Вот почему задача состоит в том, чтобы выработать единую международно-правовую конвенцию, которая определяла бы права и обязанности постоянно нейтральных государств в мирное время, а также обязательства других стран по отношению к ним.

Туркменская модель нейтралитета коренным образом меняет существовавшие до сих пор представления о нейтралитете и прежде всего исходит из того, что современное международное право есть право мира. Она может стать основой новой концепции сотрудничества и достижения регионального мира ${ }^{6}$.

Нейтралитет Туркменистана - новое явление в мировой практике, особенности которого состоят в следующем.

Во-первых, по происхождению он является признанным, о чем свидетельствует резолюция Генеральной Ассамблеи ООН "Постоянный нейтралитет Туркменистана” от 12 декабря 1995 г., в соответствии с которой все 185 членов ООН единогласно поддержали Туркменистан в обретении им статуса постоянно нейтрального государства. В этом случае важно отметить, что данный преце- 
дент не имеет аналогов в мнровой практике. Если ранее соответствующий статус то или иное государство обретало путем соглашения нескольких государств, то нейтральный статус Туркменистана поддержало практически все мировое сообщество. Кроме того, и форма международно-правового документа (резолюция Генеральной Ассамблеи ООН, в соответствии с которой оформлен статус Туркменистана) также применена впервые.

Во-вторых, нейтралитет Туркменистана не базируется на итогах каких-либо войн, соглашений великих держав, а является результатом самостоятельного выбора, добровольного волеизъявления со стороны Туркменистана.

И в-третьих, по содержанию нейтралитет Туркменистана является позитивным, или конструктивным, что подразумевает активную позицию государства в вопросах поддержания мира и стабильности, развития отношений дружбы и сотрудничества между государствами. Это не застывшее состояние, не попьтка изолироваться, это цель и средство вхождения путем согласия и партнерства в мировое сообщество.

После принятия резолюции Генеральной Ассамблеи ООН о постоянном нейтралитете Туркменистана новые реалии потребовали конституционно-правового закрепления международного статуса государства. На заседании Халк Маслахаты (Народного совета), состоявшемся 27 декабря 1995 г., были приняты дополнения к Конституции. Халк Маслахаты одобрил решение о принятии Конституционного Закона Туркменистана "О постоянном нейтралитете Туркменистана", Декларацию о международных обязательствах нейтрального Туркменистана в области прав человека, а также Концепцию внешней политики Туркменистана как нейтрального государства. Эти основополагающие документы явились фундаментом, определяющим четкие ориентиры внешнеполитического курса Туркменистана.

Правовое закрепление политики нейтралитета Туркменистана на уровне специальной резолюции $\mathrm{OOH}$ и принятие соответствующего конституционного закона обеспечивают всеобъемлющую гарантию нейтрального статуса страны. Гарантии международного сообщества состоят в соблюдении всеми членами ООН своих обязательств по отношению к Туркменистану. Исходя из этого, вытекает важное обстоятельство, что такой статус не может быть изменен или отменен в одностороннем порядке, без согласия на то всех членов $\mathrm{OOH}^{7}$.

Постоянный нейтралитет - это правовое состояние государства, особый статус, порождаюший определенные права и обязанности.

Права и обязанности Туркменистана как постоянно нейтрального государства четко определены в Конституционном Законе "О постоянном нейтралитете”. В концентрированном виде они обозна- 
чены в военно-политической, экономической и гуманитарной областях.

В военно-политической области статус постоянного нейтралитета Туркменистана предусматривает реализацию внешнеполитического курса в следующих направлениях:

1) проводить миролюбивую внешнюю политику, строить свои отношения с другими государствами на принципах равноправия, взаимоуважения и невмешательства во внутренние дела других государств;

2) не принимать участия в военных блоках и союзах, межгосударственных объединениях с жесткими обязательствами или предполагающих коллективную ответственность участников;

3) не начинать войн и военных конфликтов, не участвовать в них (кроме реализации права на самооборону), не предпринимать политических, дипломатических или иных шагов, которые могут привести к войне или военному конфликту;

4) не допускать создания иностранных военных баз на своей территории и использования ее другими государствами в военньх целях;

5) не обладать, не производить и не распространять ядерное, химическое, бактериологическое и иные виды оружия массового поражения ${ }^{8}$.

Как упоминалось выше, постоянно нейтральное государство не имеет права участвовать ни в какой из войн, кроме оборонительной, когда она совпадает с индивидуальной самообороной.

В соответствии со своей оборонительной доктриной и принятыми международными обязательствами Туркменистан имеет вооруженные силы и вооружения, достаточные для защиты его суверенитета и территориальной целостности. В случае агрессии против Туркменистана он оставляет за собой право обратиться за военной помощью $\mathrm{x}$ другому государству или государствам.

Разумеется, этот перечень нельзя считать исчерпывающим, он может быть дополнен другими положениями, которым Туркменистан, как нейтральное государство, должен строго следовать в своей деятельности. В частности, Туркменистан обязан соблюдать все международные договоры и соглашения, отвечающие общепризнанньм принципам международного права и национальным интересам. Кроме того, Туркменистан не должен укрывать лиц, ведущих подрывную деятельность против иностранного государства, допускать в пределах своей территории пропаганду, имеющую целью вызвать ненависть и вражду к иностранной державе и ее народу. Ни в мирное, ни в военное время Туркменистан, как постоянно нейтральное государство, не имеет права пропускать через свою территорию войска иностранных государств, следуюшие в другую страну для участия в войне или внутриполитических события, происходящих в 
этой стране. Территория Туркменистана не может служить базой для организации, формирования и отправки за границу такого рода отрядов, террористических групп и т.д.

Таким образом, обязанности Туркменистана в мирное время не ограничиваются его отказом от участия в военных блоках и от предоставления своей территории под иностранные военные базы. Туркменистан обязан, помимо этого, проводить миролюбивую внешнюю политику в отношении всех стран, избегая всего того, что может вовлечь его в конфликт с другими странами.

В свою очередь, государства мирового сообщества, которые поддержали резолюцию Генеральной Ассамблеи ООН от 12 декабря 1995 г. "Постоянный нейтралитет Туркменистана", обязаны по отношению к Туркменистану не прибегать к силе или угрозе силой, а также к иным мерам, которые могли бы нанести ущерб Туркменистану; воздерживаться от какого бы то ни было прямого или косвенного вмешательства в его внутренние дела; не сопровождать помошь, оказываемую Туркменистану, условиями политического харахтера; не втягивать Туркменистан ни в какие военные союзы, не совместимые с его нейтралитетом; уважать желание Туркменистана не признавать защиты со стороны какого-либо союза или военного блока; не вводить в Туркменистан иностранные войска или военный персонал и не создавать на его территории иностранные военные базы либо воинские формирования.

Главное значение постоянного нейтралитета Туркменистана выражается в проводимой им миролюбивой политике и в том, что наше государство несет в себе значительные функции мирного переговорного процесса в регионе. Не случайно, например, ООН официально уполномочила Туркменистан быть местом проведения непрерывного раунда межтаджикских переговоров. В январе 1997 года в Ашхабаде проходил международный форум по оказанию гуманитарной помощи Афганистану. Только в течение последних лет Туркменистан стал местом проведения ряда крупных международных конференций, посвященных проблемам региональной стабильности и безопасности в Центральной Азии, интеграции региона в мировую зкономику, глобального запрещения использования наземных противопехотных мин.

Несомненно, нейтралитет создает не только условия для равного отношения Туркменистана с государствами в политической сфере, но и в его экономических взаимоотношениях с ними. Утверждение за Туркменистаном статуса постоянно нейтрального государства способствовало значительной активизации проводимой в стране политики "открытых дверей". Зарубежных инвесторов привлекает законодательная база, которая еще более укрепилась с принятием 
Конституционного закона о постоянном нейтралитете. Закон предусматривает, что Туркменистан развивает международное экономическое сотрудничество на основе равноправия, взаимной выгоды и учета интересов вовлеченных в этот процесс сторон, рассматривая такое сотрудничество как важнейший инструмент укрепления доверия между странами и регионами, поддержания мира и стабильности.

За короткий период независимости, особенно после обретения Туркменистаном статуса постоянного нейтралитета, наблюдается значительное увеличение инвестиционного потока в страну. Объем капитальных вложений измеряется сегодня в размере нескольких миллиардов американских долларов, которые направлены на модернизацию таких определяющих отраслей экономики, какими являются нефтегазовая, текстильная, строительство, транспорт, связь и др. Внесение конституционных поправок в соответствии с новым статусом государства стало своеобразной преамбулой $\mathrm{K}$ реальной оценке рыночных реформ, реорганизации аграрного сектора, финансовой сферы и хода приватизации.

Конструктивные инициативы нейтрального Туркменистана придают новые импульсы и динамике развития регионального сотрудничества стран. Это особенно ярко видно на примере развития Организации экономического сотрудничества (ОЭС). Страны - члены ОЭС с более чем 310-миллионньм населением демонстрируют собой появление влиятельного субъекта международных отношений, что одновременно свидетельствует о рождении новой региональной общности, логически соответствуюшей историческим закономерностям возрождения культурно-цивилизованного единства родственных народов.

Идея нейтралитета Туркменистана основана на понимании этого единства и необходимости возрождения его в новом качестве. Логика сотрудничества стран - членов ОЭС во имя возрождения региона и процветания населяющих его народов в полном смысле совпадает с основными принципами нейтралитета Туркменистана.

В Туркменистане на высоком конституционном уровне объявлено, что высшей ценностью обшества и государства является человек. Соответствующее положение отражено и в Конституционном законе Туркменистана о постоянном нейтралитете. Туркменистан признает и уважает права и свободы человека, принятые мировым сообществом и зафиксированные в нормах международного права. Туркменистан присоединился к более чем 30 международным договорам и конвенциям в области прав человека. Этим самым в стране созданы политические, экономические, правовые и другие гарантии эффективного осушествления принятых международных обязательств. Кроме того, Туркменистан активно участвует в междуна- 
родных гуманитарных акциях, опираясь на общепринятые правовые нормы.

В реализации вышеуказанных обязательств Туркменистан максимально зффективно использует свое членство в таких международных организациях, как Детский фонд ООН (ЮНИСЕФ), Всемирная организация здравоохранения (ВО3), Организация Объединенных Наций по вопросам образования, науки и культуры (ЮНЕСКО), Международная организация труда (МОТ) и др.

В целях эффективного осуществления программы социальноэкономических преобразований, выполнения международных обя: зательств в области прав человека, проведения научно-прикладных исследований в этой области создан Туркменский национальный институт демократии и прав человека при Президенте Туркменистана.

День 12 декабря 1995 г., когда Организация Объединенных Наций официально признала нейтралитет Туркменистана, будет навсегда вписан в историю нашей страны. Признание мировьм сообществом нейтралитета Туркменистана означает его качественно новую роль в международных делах. Позитивный, миротворческий потенциал Туркменистана будет использоваться сообществом наций для решения его насущных, животрепещущих проблем. Это означает не только высокое доверие Туркменистану на уровне сообщества наций, но и большую ответственность. Теперь, получив международную поддержку, обеспечив благоприятные внешние условия, Туркменистан уверенно идет по пути цивилизованного развития, ведущего в будущее тысячелетие.

${ }^{1}$ Резолюция Генеральной Ассамблеи ООН от 12 декабря 1995 г. "Постоянный нейтралитет Туркменистана" // Туркменская искра. — 1995. 14 дек.

2 Внешняя политика нейтрального Туркменистана. Речи, выступления и интервью Президента Туркменистана Сапармурата Туркменбаши. - Ашхабад, 1997. - С. 17-18.

${ }^{3}$ Там же. - C. 27.

${ }^{4}$ Моджорян Л.А. Постоянно нейтральные государства и межцународное право // Советское государство и право. - 1955. - № 7. - С. 109; Дурденевский В.Н. Нейтралитет в системе коллективной безопасности // Советское государство и право. - 1957 . - № 8. - С. $82 ;$ Ганюшкин Б.В. Нейтралитет и неприсоединение. - М., Международные отношения. - 1965. С. 111 ; Словарь международного права. - М., Международные отношения, 1982. - С. 118-119; Международное право. Словарь-справочник / Под общей ред. акад. МАИ, д-р юр. наук В.Н. Трофимова. - М., ИНФРА-М, 1997. - С. 184-185.

${ }^{5}$ Ганюшкин Б.B. Нейтралитет и неприсоединение. - С. 109. 
- $B$. Shikhmuradov. Positive neutrality as the basis of the foreign policy of Turkmenistan // Perceptions Journal of International Affairs. - June - Aug. 1997. - P. 19.

'Е.A. Кепбанов. Нейтральный Туркменистан: права и обязанности // Вестник МИД Туркменистана. - 1996. - № 6. - С. 39; Внешнеэкономическая политиха нейтрального Туркменистана / Под ред. М.Б. Оразова.Ашхабад, 1997. - С. 15.

${ }^{8}$ Конституционный закон Туркменистана "О постоянном нейтралитете Туркменистана" (ст. 3-6)//Нейтральный Туркменистан. - 1995. 28 дек.

Статья поступила в редакцию в июне 1998 г.

\section{КОНКУРС НА КОРРУМПИРОВАННОСТЬ}

Среди многочисленных международных соревнований и конкурсов на Западе есть и такие, которые придумываются специально, чтобы унизить Россию и напугать определенные круги частного капитала с целью отвратить их от заключения контрактов и сделок с российскими фирмами или с целью отказаться от мысли инвестировать какие-то проекты в стране «медведей и преступников».

В частности, один из таких «конкурсов» провела лондонская консультативная компания «Control Risks». Она объявила, что свое мнение сформировала, опираясь на взгляды глав ведущих фирм Европы и Америки. Сам «конкурс» состоял в том, чтобы выявить самую коррумпированную страну в мире. Не объявляя о своих критериях, компания заявила, что такой страной является Россия. На втором месте - Нигерия, на третьем - Украина, далее следуют Азербайджан, Узбекистан и Казахстан. Как на какой-нибудь олимпиаде, выцвлено шесть первых мест. Кстати, свои взгляды компания подтвердила и мнением Европейского банка реконструкции и развития, который, дескать, разделяет ее точку зрения.

Взяточничество процветает и в странах Запада. Компания опубликовала данные о том, что две трети опрошенных ею представителей деловых кругов западного мира сказали, что их фирмы, случалось, не получали выгодных контрактов из-за нежелания давать мзду. В то же время Международный валютный фонд и Мировой банк высказали свою официальную позицию по поводу этого явления. Они готовы жестко противостоять таким компаниям, которые дают взятки, правда не уточнив, как конкретно. Иньми словами, происходит то, что часто случается в международном (да и во внутреннем тоже) праве: норма вроде бы имеется, но нет механизма ее осуществления.

(Соб. инф.) 